\title{
Perbedaan Rerata Kadar Soluble Fms-Like Tyrosine Kinase-1 (Sflt-1) Serum pada Penderita Early Onset, Late Onset Preeklampsia Berat / Eklampsia dan Kehamilan Normal
}

\author{
Laila Rahmi ${ }^{1}$, Rahmatina B. Herman ${ }^{2}$, Yusrawati $^{3}$
}

\begin{abstract}
Abstrak
Preeklampsia merupakan sumber utama morbiditas dan mortalitas ibu di seluruh dunia. Kegagalan pengaturan dan ketidakseimbangan agen vasoaktif proangiogenik dan antiangiogenik plasenta, soluble fms-like tyrosine kinase-1 (sFlt-1), vascular endothelial growth factor (VEGF) dan placental growth factor (PIGF) memainkan peran penting dalam patogenesis preeklampsia. Tujuan penelitian ini adalah menentukan perbedaan rerata kadar sFlt-1 serum pada penderita early onset, late onset preeklampsia berat/ eklampsia dan kehamilan normal. Penelitian dilakukan di RSUP Dr. M. Djamil, RS TK. III dr. Reksodiwiryo dan Laboratorium Biologi Molekuler Fakultas Kedokteran Universitas Andalas Padang dari Februari sampai Desember 2014 dengan desain cross sectional. Subjek berjumlah 84 orang, terdiri dari tiga kelompok, yaitu kelompok early onset preeklampsia berat/ eklampsia, late onset preeklampsia berat/ eklampsia, dan kehamilan normal sebagai kelompok kontrol yang diambil dengan teknik consecutive sampling. Darah dikumpulkan dari subjek penelitian dengan cara intravena kemudian diukur dengan metode ELISA. Rerata kadar sFIt-1 pada kelompok early onset, late onset preeklampsia berat/ eklampsia dan kehamilan normal secara berturut-turut adalah 4,69 $\pm 0,96 \mathrm{ng} / \mathrm{ml}, 2,39 \pm 0,57 \mathrm{ng} / \mathrm{ml}$, dan 1,23 $\pm 0,42 \mathrm{ng} / \mathrm{ml}$. Perbedaan ini sangat signifikan dengan uji statistik ANOVA $(p<0,05)$ dan uji Post Hoc Test Multiple Comparisons. Kesimpulan penelitian adalah terdapat perbedaan yang sangat signifikan antara kadar sFlt-1 serum pada kelompok early onset preeklampsia berat/ eklampsia, late onset preeklampsia berat/ eklampsia dan kehamilan normal.
\end{abstract}

Kata kunci: sFlt-1, antiangiogenik, preeklampsia berat/ eklampsia, kehamilan normal

\begin{abstract}
Preeclampsia is a major cause maternal morbidity and mortality in the world. Failure regulation and imbalance of vasoactive agents and antiangiogenic proangiogenik placenta, soluble fms-like tyrosine kinase-1 (sFlt-1), vascular endothelial growth factor (VEGF) and placental growth factor (PIGF) have an important role in the pathogenesis of preeclampsia. The objective of this study was to determine the differences between the mean serum levels of sFlt-1 in patients with early onset, late onset severe preeclampsia/eclampsia and normal pregnancy. This study was conducted in Dr. M. Djamil hospital, dr. Reksodiwiryo TK. III hospital and Biology Moleculer Laboratory Medicine Faculty of Andalas University Padang from February until December 2014 with a cross sectional design. The total subjects were 84 persons, consist of three groups, there was early onset severe preeclampsia/ eclampsia, late onset severe preeclampsia/ eclampsia and normal pregnancy as control group. The subjects were selected by consecutive sampling technique. The blood was collected by intravenous, then sFlt-1 serum measured by ELISA. The mean levels of sFlt-1 in the early onset group, late onset severe preeclampsia/ eclampsia group and normal pregnancy group were $4.69 \pm 0.96 \mathrm{ng} / \mathrm{ml}, 2.39 \pm 0.57 \mathrm{ng} / \mathrm{ml}$ and $1.23 \pm 0.42 \mathrm{ng} / \mathrm{ml}$. This difference very significant by ANOVA statisctical test $(p<0,05)$ and Multiple Comparisons Post Hoc Test. The conclusion of this study is very significant differences between serum levels of sFlt-1 in early onset severe preeclampsia/ eclampsia group, late onset severe preeclampsia/ eclampsia on normal pregnancy.
\end{abstract}

Keywords: sFlt-1, antiangiogenic, severe preeclampsia/ eclampsia, normal pregnancy 
Affiliasi penulis: 1. Program Studi S-2 Magister Kebidanan FK UNAND (Fakultas Kedokteran Universitas Andalas Padang), 2. Bagian Fisiologi FK UNAND, 3. Bagian Obstetri dan Gynekologi FK UNAND / RSUP Dr. M. Djamil Padang.

Korespondensi: Laila Rahmi, email: laila_sitiazzahra@yahoo.co.id, Telp: 085263453245

\section{PENDAHULUAN}

Mortalitas pada ibu hamil dan bersalin masih merupakan tantangan utama bagi kesehatan masyarakat meskipun sudah banyak strategi yang dirancang oleh komunitas internasional untuk mengatasinya. Kematian ibu secara global adalah penyebab utama kematian di kalangan perempuan berusia 15-49 tahun. Lebih dari 1.500 wanita meninggal di setiap harinya karena berkaitan dengan kehamilan yang mengakibatkan sekitar 550.000 kematian ibu per tahunnya. ${ }^{1}$

Preeklampsia merupakan sumber utama morbiditas dan mortalitas di seluruh dunia, serta merupakan penyulit 3\%-8\% kehamilan di negaranegara Barat. $^{2,3}$ Secara global, 10\%-15\% kematian maternal secara langsung berhubungan dengan preeklampsia dan eklampsia. Di Amerika Serikat, preeklampsia secara signifikan mempengaruhi 5\%-8\% dari seluruh kehamilan dan merupakan penyebab utama ketiga kematian ibu setelah emboli dan perdarahan. $^{3} \quad \mathrm{Di}$ Indonesia, angka kejadian preeklampsia dan eklampsia berkisar antara 6\%-8\% pada seluruh wanita hamil. ${ }^{4}$

Preeklampsia adalah penyakit sistemik maternal yang ditandai dengan timbulnya hipertensi dan proteinuria setelah usia kehamilan 20 minggu dan merupakan penyebab morbiditas dan mortalitas maternal-perinatal di seluruh dunia. Meskipun etiologi preeklampsia tidak dipahami, satu model hipotesis patofisiologis berpendapat bahwa preeklampsia berkembang karena adanya kelainan plasentasi dan gangguan penerjemahan terhadap sistemik maternal. ${ }^{5}$

Kumpulan bukti penelitian menunjukkan bahwa kondisi utama dalam patofisiologi preeklampsia adalah kegagalan transformasi fisiologis arteri spiralis, yang menjadi dasar pemikiran terjadinya plasentasi yang buruk dan berkurangnya suplai darah ke plasenta pada awal kehamilan. Pada tahapan selanjutnya plasenta akan melepaskan faktor-faktor bioaktif ke dalam sirkulasi ibu sehingga menyebabkan disfungsi sel endotel sistemik, perubahan metabolik, adanya pro-trombotik, aktivasi faktor keseimbangan, peradangan intravaskular dan kerusakan di berbagai organ. ${ }^{6}$

Etiologi dan patogenesis preeklampsia tidak sepenuhnya dipahami, namun hal ini diduga berawal dari plasenta dengan sasaran endothelium ibu. Kegagalan pengaturan dan ketidakseimbangan agen vasoaktif proangiogenik dan antiangiogenik plasenta, soluble fms-like tyrosine kinase1 (sFlt-1), vascular endothelial growth factor (VEGF) dan placental growth factor (PIGF) memainkan peranan yang penting dalam patogenesis preeklampsia. ${ }^{7}$

Levine et al pada tahun 2004 telah meneliti protein proangiogenik dan antiangiogenik dalam sirkulasi darah ibu preeklampsia ${ }^{8}$. sFlt-1 yang juga dikenal sebagai reseptor-1 faktor soluble VEGF adalah protein antiangiogenik yang meningkat sebelum timbulnya penyakit klinis pada wanita dengan preeklampsia. $^{8-11}$

Bukti menunjukkan bahwa sentral dari patofisiologi preeklampsia adalah ketidakseimbangan antara peredaran faktor angiogenik (VEGF dan PIGF), dan faktor antiangiogenik (sFlt-1 dan soluble Endoglin (sEng)). ${ }^{12}$ Konsentrasi plasma VEGF dan PIGF ditemukan lebih rendah sedangkan konsentrasi plasma sFlt-1 dan sEng ditemukan lebih tinggi pada penderita preeklampsia dibandingkan dengan hamil normal. Penentuan konsentrasi faktor angiogenik dan antiangiogenik plasma/serum ibu telah diusulkan sebagai parameter yang dapat membantu mengidentifikasi wanita yang berpotensi mengalami preeclampsia. $^{13}$

Preeklampsia telah digambarkan sebagai dua penyakit yang berbeda, yaitu early onset preeklampsia (berkembang sebelum usia kehamilan 34 minggu), dan late onset preeklampsia (berkembang pada atau setelah usia kehamilan 34 minggu). ${ }^{14}$ Early onset preeklampsia sangat terkait dengan gangguan invasi trofoblas dan kegagalan remodeling arteri spiralis, sedangkan late onset preeklampsia disebabkan oleh peningkatan kerentanan pembuluh darah ibu dengan 
keadaan inflamasi terhadap kehamilan normal atau atherosis plasenta yang awalnya berkembang dengan normal. $^{15}$

Villa et al pada tahun 2013, menemukan bahwa konsentrasi sFlt-1 serum secara signifikan lebih tinggi pada penderita yang selanjutnya akan mengalami early onset preeklampsia dibandingkan dengan penderita yang mengalami late onset preeklampsia. ${ }^{7}$

Govender et al pada tahun 2012 menemukan bahwa konsentrasi serum sFlt-1 pada kelompok ibu hamil normotensif secara signifikan lebih rendah dibandingkan kelompok early onset preeklampsia, sedangkan konsentrasi serum sFlt-1 pada kelompok early dan late onset preeklampsia lebih tinggi dibandingkan kelompok hipertensi kronis. ${ }^{16}$

Putra pada tahun 2010 mendapatkan hubungan faktor biologik terhadap kadar sFlt-1 serum pada wanita hamil dengan preeklampsia berat. Kadar sFlt-1 ditemukan lebih tinggi pada ibu primipara, ibu bersalin dengan usia berisiko $(<20$ tahun dan $>35$ tahun), dan ibu dengan riwayat preeclampsia. ${ }^{17}$

Tujuan penelitian ini adalah untuk menentukan perbedaan rerata kadar sFlt-1 serum pada penderita early onset, late onset preeklampsia berat/ eklampsia, dan kehamilan normal.

\section{METODE}

Penelitian ini merupakan studi observasional dengan pendekatan cross sectional. Penelitian dilakukan di RSUP Dr. M. Djamil Padang dan RS. TK. III dr. Reksodiwiryo Padang dari Februari sampai Desember 2014. Pemeriksaan kadar sFlt-1 serum dilakukan di Laboratorium Biologi Molekuler Fakultas Kedokteran Universitas Andalas Padang.

Populasi pada penelitian ini adalah semua ibu hamil dengan usia kehamilan $\geq 20$-42 minggu dengan diagnosis preeklampsia berat/ eklampsia dan ibu hamil kehamilan normal. Sampel pada penelitian ini adalah bagian dari populasi yang memenuhi kriteria inklusi dan eksklusi penelitian. Kriteria inklusi adalah ibu hamil dengan usia kehamilan $\geq 20-42$ minggu, terdiagnosis mengalami penyakit preeklampsia berat / eklampsia dan ibu hamil normal berdasarkan gejala klinis dan hasil laboratorium, kehamilan tunggal, dan bersedia menjadi responden dalam penelitian. Kriteria eksklusi yaitu ibu hamil dengan kematian janin dalam rahim dan kehamilan ganda.

Besaran sampel pada penelitian ini digunakan

$$
\begin{aligned}
& \begin{array}{l}
\text { rumus: } \\
\qquad N_{1}=N_{2}=2\left[\frac{(Z \alpha+Z \beta) S}{X_{1}-X_{2}}\right]^{2}
\end{array} \\
& \mathrm{~N}=\text { Jumlah sampel yang dicar } \\
& \mathrm{Za}=\text { Deviat baku alfa/ Kesalahan tipe I (a) } \\
& \text { sebesar } 5 \%=1,96 \\
& \mathrm{Z} \beta=\text { Deviat baku beta/ Kesalahan tipe II }(\beta) \\
& \text { sebesar } 10 \%=1,282 \\
& \mathrm{~S}=\text { Standar deviasi (gabungan) }=2292,41 \\
& \mathrm{X}_{1}-\mathrm{X}_{2}=\text { Selisih minimal rerata yang dianggap }
\end{aligned}
$$

Jumlah subjek pada penelitian ini adalah 84 orang (terdiri dari 3 kelompok penelitian) dengan pengambilan sampel yang dilakukan menggunakan teknik consecutive sampling. Pemeriksaan kadar sFlt1 serum dilakukan dengan cara pengambilan darah pada vena mediana cubiti sejumlah 2 cc menggunakan spuit $3 \mathrm{ml}$, kemudian disentrifuse untuk mendapatkan serum sebanyak \pm 100 mikron untuk selanjutnya dilakukan pemeriksaan kadar sFlt-1 serum dengan menggunakan metode ELISA. Data kadar sFlt-1 dianalisis dengan menggunakan uji ANOVA. Untuk mengetahui kelompok yang memiliki perbedaan yang signifikan dari ketiga kelompok yang ada dilanjutkan dengan analisis multi comparison (Post Hoc Test).

\section{HASIL}

Setelah dilakukan observasi dan seleksi, didapatkan 84 orang ibu hamil yang memenuhi kriteria inklusi, 28 orang ibu hamil dengan early onset preeklampsia berat/ eklampsia, 28 orang ibu hamil dengan late onset preeklampsia berat/ eklampsia, dan 28 orang ibu hamil dengan kehamilan normal. Gambaran karakteristik subjek penelitian dapat dilihat pada tabel berikut. 
Tabel 1. Distribusi frekuensi karakteristik subjek penelitian pada kelompok early onset, late onset preeklampsia berat/ eklampsia, dan kehamilan normal

\begin{tabular}{|c|c|c|c|c|c|c|c|c|}
\hline & & & & & & & & \\
\hline & & & & & & & & \\
\hline & Karakteristik & Preekl & Berat/ & Pre & psia & Kehar & ormal & $\mathbf{p}$ \\
\hline & & & & Bera & mpsia & & & \\
\hline & & & & & & & & \\
\hline 1. & Umur (tahun) & & & & & & & \\
\hline & Mean $\pm S D$ & & & & ,21 & & & 0,07 \\
\hline 2. & Paritas & & & & & & & \\
\hline & Mean $\pm S D$ & & & & & & & 0,11 \\
\hline 3. & Riwayat Preeklampsia & $f$ & $\%$ & $f$ & $\%$ & $f$ & $\%$ & \\
\hline & Ada Riwayat & 0 & 0 & 1 & 3,6 & 0 & 0 & \\
\hline & Tidak Ada Riwayat & 28 & 100 & 27 & 96,4 & 28 & 100 & 0,36 \\
\hline 4. & Riwayat Hipertensi & $f$ & $\%$ & $f$ & $\%$ & $f$ & $\%$ & \\
\hline & Ada Riwayat & 1 & 3,6 & 2 & 7,1 & 0 & 0 & \\
\hline & Tidak Ada Riwayat & 27 & 96,4 & 26 & 92,9 & 28 & 100 & 0,36 \\
\hline
\end{tabular}

Tabel 1 menunjukkan bahwa hasil uji statistik pada semua karakteristik menunjukkan tidak terdapat hubungan yang signifikan antara umur responden, paritas, riwayat preeklampsia dan riwayat hipertensi pada kelompok early onset dan late onset preeklampsia berat/ eklampsia, dan kehamilan normal ( $p=0,07, p=0,11, p=0,36$, dan $p=0,36)$.

Berdasarkan hasil pemeriksaan dan uji statistik, rerata kadar sFlt-1 serum pada 3 kelompok penelitian dapat dilihat pada tabel berikut ini :

Tabel 2. Distribusi rerata kadar sFlt-1 Serum pada kelompok early onset, late onset preeklampsia berat/ eklampsia, dan kehamilan normal

\begin{tabular}{lcccc}
\hline \multirow{1}{*}{ Kelompok } & \multicolumn{3}{c}{ Kadar sFlt-1 Serum } \\
& \multicolumn{3}{c}{ (ng/ml) } & p \\
\cline { 2 - 4 } & Mean & SD & $\mathbf{9 5 \%} \mathbf{~ C l}$ & \\
\hline Early Onset & 4,69 & 0,96 & $4,32-$ & \\
Preeklampsia Berat/ & & & 5,06 & 0,000 \\
Eklampsia & & & & \\
Late Onset & 2,39 & 0,57 & $2,18-$ & \\
Preeklampsia Berat/ & & & 2,62 & \\
Eklampsia & & & \\
Kehamilan Normal & 1,23 & 0,42 & $1,07-$ \\
& & & 1,39 \\
\hline
\end{tabular}

Berdasarkan Tabel 2 dapat dilihat bahwa rerata kadar sFlt-1 serum pada kelompok early onset preeklampsia berat/ eklampsia adalah 4,69 $\pm 0,96$ $\mathrm{ng} / \mathrm{ml}$. Pada kelompok late onset preeklampsia berat/ eklampsia adalah 2,39 $\pm 0,57 \mathrm{ng} / \mathrm{ml}$ dan kelompok kehamilan normal adalah 1,23 $\pm 0,42 \mathrm{ng} / \mathrm{ml}$. Hasil ini memperlihatkan bahwa kadar sFlt-1 serum pada pada kelompok early onset preeklampsia berat / eklampsia hampir 2 kali lipat dibandingkan kelompok late onset preeklampsia berat/ eklampsia. Kadar sFlt-1 serum pada kelompok late onset preeklampsia berat/ eklampsia hampir 2 kali lipat dibandingkan kelompok kehamilan normal.

Hasil uji statistik dengan ANOVA menunjukkan nilai $p=0,000 \quad(p<0,05)$, berarti terdapat perbedaan yang kadar sFlt-1 serum sangat signifikan antara kelompok early onset preeklampsia berat/ eklampsia, late onset preeklampsia berat/ eklampsia, dan kehamilan normal. Perbedaan antara kelompok penelitian dilanjutkan dengan Uji Post Hoc Test Multiple Comparisons. Hasil uji lanjutan tersebut dapat dilihat pada Tabel 3 berikut ini :

Berdasarkan Tabel 3 terlihat bahwa perbedaan yang sangat signifikan terdapat pada kelompok early onset preeklampsia berat/eklampsia dengan kelompok late onset preeklampsia berat/eklampsia dan kehamilan normal, kelompok late onset preeklampsia berat/eklampsia dengan kelompok early onset preeklampsia berat/ eklampsia dan kehamilan normal, kelompok kehamilan normal dengan kelompok early onset preeklampsia berat/ eklampsia dan late onset preeklampsia berat/ eklampsia. 
Tabel 3. Hasil uji post hoc test rerata kadar sFlt-1 serum antar kelompok penelitian

\begin{tabular}{|c|c|c|c|}
\hline Kelompok & $\begin{array}{c}\text { Early Onset } \\
\text { Preeklampsia Berat/ } \\
\text { Eklampsia }\end{array}$ & $\begin{array}{c}\text { Late Onset } \\
\text { Preeklampsia Berat/ } \\
\text { Eklampsia }\end{array}$ & Kehamilan Normal \\
\hline Early Onset & & & \\
\hline $\begin{array}{l}\text { Preeklampsia Berat/ } \\
\text { Eklampsia }\end{array}$ & - & $0,000^{*}$ & $0,000^{*}$ \\
\hline $\begin{array}{l}\text { Late Onset } \\
\text { Preeklampsia Berat/ } \\
\text { Eklampsia }\end{array}$ & $0,000^{*}$ & - & $0,000^{*}$ \\
\hline $\begin{array}{l}\text { Kehamilan } \\
\text { Normal }\end{array}$ & $0,000^{*}$ & $0,000^{*}$ & - \\
\hline
\end{tabular}

\section{PEMBAHASAN}

Bukti menunjukkan bahwa pada preeklampsia terjadi ketidakseimbangan antara faktor angiogenik dan antiangiogenik plasenta yang dapat membahayakan vaskular endotel dan memunculkan gejala klinis pada ibu. ${ }^{18}$ Evaluasi terhadap berbagai faktor angiogenik dan antiangiogenik pada serum dan plasma ibu telah diuji sebagai penanda diagnostik preeklampsia untuk kemungkinan penggunaannya dalam memprediksi perkembangan preeklampsia.,19 dan kadar serum dari sFlt-1 ditemukan terlibat pada preeklampsia. $^{18}$ Berdasarkan penelitian yang dilakukan pada hewan percobaan untuk melihat peran patologis faktor antiangiogenik sFlt-1, tikus hamil tersebut memperlihatkan sindrom preeklampsia setelah diberikan adenovirus yang mengekspresikan sFlt-1. ${ }^{20}$ Pada manusia, kadar serum dari faktor pertumbuhan plasenta (PIGF) berkurang pada wanita dengan preeklampsia. ${ }^{21}$ Peningkatan sFlt-1 dan penurunan PIGF telah muncul dalam serum ibu 5 sampai 10 minggu sebelum timbulnya preeklampsia dan telah ditetapkan bahwa perubahan sFlt-1 dan PIGF ini berkontribusi pada patogenesis preeklampsia. $^{8,9}$

Potensi prediksi sFlt-1 dan sEng telah menarik perhatian besar di bidang penelitian preeklampsia dalam beberapa tahun terakhir, temuan terbaru memberikan bukti yang menunjukkan bahwa kadar sFlt-1 dan sEng berkaitan dengan patologi preeklampsia. $^{22}$

Hasil penelitian ini selaras dengan penelitian yang dilakukan oleh Lee et al pada tahun 2007 yang menemukan bahwa konsentrasi sFlt-1 serum secara signifikan mengalami peningkatan pada pasien dengan preeklampsia dibandingkan dengan ibu hamil tanpa komplikasi. Terdapat korelasi positif antara konsentrasi serum sFlt-1 dengan tekanan darah sistolik dan diastolik, dan menyimpulkan bahwa sFlt-1 berkaitan dengan patogenesis preeklampsia. ${ }^{23}$

Begitu juga dengan hasil penelitian yang dilakukan oleh Reddy et al pada tahun 2009 yang menemukan bahwa kadar sFlt-1 dan sEng secara signifikan ditemukan lebih tinggi pada penderita preeklampsia dibandingkan dengan ibu hamil normal. Pada persalinan, kadar sFlt-1 meningkat secara signifikan saat dilatasi maksimal pada penderita preeklampsia, sebelum menurun pada 24 jam pertama post partum. ${ }^{24}$

Noori et al pada tahun 2010 menemukan bahwa ibu hamil dengan preeklampsia memiliki tingkat sFlt-1 yang lebih tinggi dibandingkan dengan ibu hamil dengan normotensi. Selama masa kehamilan, penghambatan faktor pertumbuhan endotel vaskular oleh sFlt-1 menyebabkan terjadinya gangguan pertumbuhan endotel dan terjadinya proteinuria. $^{25}$

Govender et al pada tahun 2012 menemukan konsentrasi sFlt-1 serum pada kelompok tekanan darah normal $(9.603 \pm 1.797 \mathrm{pg} / \mathrm{ml})$ secara signifikan lebih kecil dibandingkan dengan kelompok early onset preeklampsia $(26.682 \pm 5.482 \mathrm{pg} / \mathrm{ml}) \quad(p<0,05)$. Dan konsentrasi sFlt-1 serum pada kelompok early onset dan late onset preeklampsia $(16.069 \pm 4.305 \mathrm{pg} / \mathrm{ml})$ lebih tinggi dibandingkan dengan kelompok hipertensi kronis $(8.811 \pm 2.008 \mathrm{pg} / \mathrm{ml})$, namun perbedaan ini ditemukan tidak berbeda secara signifikan. Dua hal yang menjadi keterbatasan dalam penelitian ini adalah kecilnya ukuran sampel yang dapat mempengaruhi 
hasil secara statistik, dan tidak mengukur/ menilai tingkat serum angiotensin II dan autoantibodi AT1. ${ }^{16}$

Protein antiangiogenik sFlt-1 yang menghambat protein proangiogenik plasenta (faktor pertumbuhan (PIGF) dan VEGF) dilaporkan mengalami peningkatan sebelum timbulnya preeklampsia. Sirkulasi sFlt-1 berkorelasi dengan timbulnya hipertensi atau proteinuria sebagai tanda preeklampsia. Ketidakseimbangan dalam sirkulasi faktor angiogenik berhubungan dengan disfungsi endotel pembuluh darah dan sindrom ibu dengan preeklampsia. $^{9}$

Keberadaan faktor proangiogenik VEGF dan PIGF yang dinamis dalam kehamilan, diperlukan selsel endotel untuk berfungsi dengan baik dan mampu bertahan hidup untuk waktu yang lama. Ketika tingkat plasma sFlt-1 naik, mereka dapat mengurangi sirkulasi tingkat VEGF dan PIGF di bawah ambang batas kritis yang diperlukan untuk pemeliharaan pembuluh darah pada orang dewasa. Disfungsi endotel yang dihasilkan dapat mengganggu sawar darah-otak dan menyebabkan hipertensi intrakranial, mengakibatkan edema di hati, dan mempengaruhi fungsi glomerulus. Eremina et al tahun 2003 menunjukkan bahwa fungsi kapiler glomerulus berada di bawah kendali VEGF. ${ }^{26}$ Artinya, ketika tingkat VEGF di prodosit ginjal turun $50 \%$, sel-sel endotel glomerulus membengkak, loop kapiler runtuh, dan proteinuria berkembang seperti yang terjadi pada penderita preeklampsia. Disfungsi endotel juga dapat mengganggu homeostasis dan memicu trombositopenia. Dengan menginduksi vasodilatasi, VEGF juga menginduksi hipotensi, dan dengan demikian peredaran tingkat VEGF yang rendah akan menyebabkan tekanan darah tinggi, ciri lain preeklampsia. Dengan demikian, hipotesis sFlt1 memungkinkan usulan model pemersatu, menjelaskan beberapa gejala preeklampsia. ${ }^{27}$

Selama kehamilan, penghambatan faktor pertumbuhan endotel vaskular dengan sFlt-1 menghasilkan gangguan fungsi endotel dan proteinuria. $^{18}$ Sejalan dengan pengamatan ini, kami menemukan bahwa wanita dengan preeklampsia memiliki kenaikan tingkat sFlt-1 yang lebih besar dibandingkan dengan wanita dengan hipertensi gestasional atau kehamilan normotensif. Namun, menjelang akhir kehamilan, ada peningkatan sFlt-1 tingkat di semua kelompok, termasuk ibu hamil dengan tekanan darah normal, yang dapat memberikan kontribusi pada peningkatan albuminuria terlihat pada kehamilan yang sehat. ${ }^{28}$

Pada penelitian ini terlihat bahwa rerata kadar sFlt-1 serum pada kelompok early onset preeklampsia berat/ eklampsia lebih tinggi $(4,69 \pm 0,96 \mathrm{ng} / \mathrm{ml})$ dibandingkan dengan kelompok late onset preeklampsia berat/ eklampsia $(2,39 \pm 0,57 \mathrm{ng} / \mathrm{ml})$, dan juga daripada kelompok kehamilan normal $(1,23 \pm 0,42$ $\mathrm{ng} / \mathrm{ml}$ ), serta terdapatnya perbedaan yang sangat signifikan antara ketiga kelompok penelitian. Lebih tingginya kadar sFlt-1 serum yang ditemukan pada kelompok early onset dan late onset preeklampsia dibandingkan dengan kehamilan normal menunjukkan bahwa adanya ketidakseimbangan faktor angiogenik dan anti-angiogenik yang dimulai pada tingkat plasenta di awal dan akhir onset preeklampsia.

\section{KESIMPULAN}

Rerata kadar sFlt-1 serum pada penderita early onset preeklampsia berat/ eklampsia lebih tinggi dibandingkan dengan rerata kadar sFlt-1 serum pada penderita late onset preeklampsia berat/ eklampsia, dan rerata kadar sFlt-1 serum pada penderita late onset preeklampsia berat/ eklampsia lebih tinggi dibandingkan dengan rerata kadar sFlt-1 serum pada kehamilan normal.

\section{UCAPAN TERIMA KASIH}

Terima kasih kepada Direktur RSUP Dr. M. Djamil Padang, Ketua RS TK. III dr. Reksodiwiryo Padang sebagai tempat penelitian atas fasilitas yang telah diberikan, Ketua Bagian Laboratorium Biologi Molekuler Fakultas Kedokteran Universitas Andalas Padang sebagai tempat pemeriksaan sFlt-1 serum.

\section{DAFTAR PUSTAKA}

1. UN. Preventable maternal mortality and morbidity and human rights. General Assembly Geneva: Human Rights Council; 2009.

2. Carty DM, Delles C, Dominiczak AF. Preeclampsia and future maternal health. Journal of Hypertensi. 2010;(28):1349-55.

3. Duley L. The global impact of pre-eclampsia and eclampsia. Semin Perinatol. 2009;(8):130-7. 
4. Roeshadi. Upaya menurunkan angka kesakitan dan angka kematian ibu pada penderita preeklampsia dan eklampsia. Pidato pengukuhan jabatan guru besar tetap Fakultas Kedokteran. Universitas Sumatera Utara Medan; 2006.

5. Haggerty CL, Seifert ME, Tang G, Orsen J, Bass DC, Karumanchi $A$, et al. Second trimester antiangiogenic proteins and preeclampsia. Pregnancy Hypertensi. NIH Public Access. 2012. April 1; 2(2): 158-63.

6. Soto E, Romero R, Kusanovic JP, Ogge G, Hussein $Y$, Yeo L, et al. Late-onset preeclampsia is associated with an imbalance of angiogenic and anti-angiogenic factors in patients with and without placental lesions consistent with maternal underperfusion. Journal Maternal Fetal Neonatal Med. NIH Public Access. 2012. May;25(5):498507.

7. Villa PM, Hämäläinen E, Mäki A, Räikkönen K, Pesonen AK, Taipale $P$, et al. Vasoactive agents for the prediction of early- and late-onset preeclampsia in a high-risk cohort. BMC Pregnancy and Childbirth. 2013;13:110.

8. Levine RJ, Maynard SE, Qian C, Lim KH, England $\mathrm{LJ}, \mathrm{Yu} \mathrm{KF}$, et al. Circulating angiogenic factors and the risk of preeclampsia. The New England Journal of Medicine. 2004;350(12):672-83.

9. Levine RJ, Lam C, Qian C, Yu KF, Maynard SE, Sachs BP, et al. Soluble endoglin and other circulating antiangiogenic factors in preeclampsia. The New England Journal of Medicine. 2006; 355(14):992-1005.

10. Maynard SE, Epstein FH, Karumanchi SA. Preeclampsia and angiogenic imbalance. Annu Rev Med; 2008;59(18):61-78.

11. Wikstrom AK, Larsson A, Eriksson UJ, Nash $P$, Norden-Lindeberg S, Olovsson M. Placental growth factor and soluble FMS-like tyrosine kinase1 in early onset and late-onset preeclampsia. Obstetri and Gynecology.June 2007;109(6):136874.

12. Kusanovic JP, Romero R, Chaiworapongsa T, Erez $\mathrm{O}$, Mittal $\mathrm{P}$, Vaisbuch $\mathrm{E}$, et al. A prospective cohort study of the value of maternal plasma concentrations of angiogenic and anti-angiogenic factors in early pregnancy and midtrimester in the identification of patients destined to develop preeclampsia. Journal of Maternal and Fetal Neonatal Medicine. 2009;22(11):1021-38.

13. Espinoza J, Romero R, Nien JK, Gomez R, Kusanovic JP, Goncalves LF, et al. Identification of patients at risk for early onset and/ or severe preeclampsia with the use of uterine artery doppler velocimetry and placental growth factor. American Journal of Obstetrics and Gynecology. 2007;196: 326-13.

14. Raymond D, Peterson E. A critical review of earlyonset and late-onset preeclampsia. Obstetrics and Gynecology Survey. 2011;66(10):497-506.

15. Costa Fda S, Murthi P, Keogh R, Woodrow N. Early screening for preeclampsia. Review of Brasil Ginecology and Obstetry. 2011;(339):367-75.

16. Govender L, Mackraj I, Gathiram P, Moodley J. The role of angiogenic, anti-angiogenic and vasoactive factors in pre-eclamptic african women: early- versus late-onset pre-eclampsia. Cardiovascular Journal of Africa. 2012;23(3):153-9.

17. Putra RW. Hubungan faktor biologik terhadap kadar sFlt-1 serum pada wanita hamil dengan preeklampsia berat (tesis). Padang: Fakultas Kedokteran Universitas Andalas; 2010.

18. Maynard SE, Min JY, Merchan J, Lim KH, Li J, Mondal S, et al. Excess placental soluble fms-like tyrosine kinase-1 (sFlt1) may contribute to endothelial dysfunction, hypertension, and proteinuria in preeclampsia. Journal Clin Invest. 2003;11:649-58.

19. Koga K, Osuga Y, Yoshino O, Hirota Y, Ruimeng $X$, Hirata $T$, et al. Elevated serum soluble vascular endothelial growth factor receptor 1 (sVEGFR-1) levels in women with preeclampsia. Journal of Clinical Endocrinology and Metabolism. 2003; 88(5):2348-23.

20. Venkatesha S, Toporsian M, Lam C, Hanai J, Mammoto T, Kim YM, et al. Soluble endoglin contributes to the pathogenesis of preeclampsia. Nature of Medicine. 2006;12(6):642-9.

21. Taylor RN, Grimwood J, Taylor RS. Longitudinal serum concentrations of placental growth factor: evidence for abnormal placental angiogenesis in pathologic pregnancies. The American Journal of Obstetrics and Gynecology. 2003;188(6):177-82.

22. Liu Z, Afink GB, Dijke P. Soluble fms-like tyrosine kinase 1 and soluble endoglin are elevated 
circulating anti-angiogenic factors in pre-eclampsia. Pregnancy Hypertension: An International Journal of Women's Cardiovascular Health 2. 2012:358-67.

23. Lee ES, Oh MJ, Jung JW, Lim JE, Seol Hj, Lee KJ, et al. The levels of circulating vascular endothelial growth factor and soluble flt-1 in pregnancies complicated by preeclampsia. Journal Korean Medicine Science. 2007;22(5): 94-8.

24. Reddy, A, Suri, S, Sargent, IL, Redman CW, Muttukhrisna S. Maternal circulating levels of activin $A$, inhibin $A$, sflt-1 and endoglin at parturition in normal pregnancy and pre-eclampsia. PLoS ONE. 2009 February; 4(2): e4453.

25. Noori M, Donald AE, Angelakopoulou A, Hingorani $A D$, Williams DJ. Prospective study of placental angiogenic factors and maternal vascular function before and after preeclampsia and gestational hypertension. Circulation. 2010;122(10):478-87.

26. Eremina V, Sood M, Haigh J, Nagy A, Lajoie G, Ferrara N, et al. Glomerular-specific alterations of VEGF-A expression lead to distinct congenital and acquired renal diseases. Journal of Clinical Investigation. 2003;111:707-16.

27. Luttun A, Carmeliet P. Soluble VEGF receptor Flt1: the elusive preeclampsia factor discovered?. The Journal of Clinical Investigation. 2003;111(3): 600-2.

28. Wallis AB, Saftlas AF, Hsia J, Atrash HK. Secular trends in the rates of preeclampsia, eclampsia, and gestational hypertension, United States, 19872004. American Journal of Hypertensi. 2008; 21(6): 521-6. 